\title{
DESAIN SISTEM E-ASSESSMENT PADA PEMBELAJARAN FISIKA DI LPTK
}

\author{
Hairunnisyah Sahidu', Gunawan', Indriaturrahmi², Fitri Astutik ${ }^{2}$ \\ ${ }^{1}$ Program Studi Pendidikan Fisika, Universitas Mataram, Indonesia \\ ${ }^{2}$ Program Studi Teknologi Pendidikan, IKIP Mataram, Indonesia \\ e-mail: hairunisyahsahidu@ gmail.com
}

\begin{abstract}
$\overline{\text { Abstract - Computer technology can be used in learning assessment activities, commonly called e- }}$ assessment. Assessment is an important part of learning. This study aims to develop an e-assessment model using Leraning management System (LMS) based on Moodle. This development research uses DDD-E model, including decision, design, develop and evaluate. Development of e-assesement using Moodle 3.3 software. This model produces e-assessment products that can be accessed online and can help learners in evaluating their learning outcomes independently. In addition, this model also encourages motivation and problem solving in the given lesson.
\end{abstract}

Keywords: e-assessment, learning management system, Moodle, pre-service physics' teacher

\section{PENDAHULUAN}

Perkembangan teknologi informasi dan komputer yang semakin canggih pada abad ini, membawa dampak yang signifikan dalam kehidupan sehari-hari salah satunya dalam bidang pendidikan. Pemanfaatan teknologi informasi dan komputer dalam dunia pendidikan sering digunakan sebagai media pembelajaran dan evaluasi pembelajaran. Dalam pendidikan fisika komputer dapat digunakan untuk menunjang pelaksanaan pembelajaran fisika, yaitu untuk mengumpulkan, menyajikan, dan mengolah data (Finkelstein, et al, 2005). Teknologi informasi dan komunikasi memainkan peran penting dalam perencanaan pembelajaran dan pengelolaannya yang memiliki beberapa keunggulan spesifik (Herga \& Dinevski 2012).

Perkembangan di bidang ICT memberikan pengaruh yang signifikan terhadap proses pembelajaran khususnya pada efektifitas pembelajaran, efisiensi waktu dan fasilitas pendukung pembelajaran lainnya (Gunawan et al, 2015). Hal terpenting dalam dunia pendidikan adalah proses pengajaran dan penilaian, pengajaran untuk menyampaikan informasi kepada peserta didik dan penilaian untuk mengevaluasi hasil dari pengajaran yang diberikan. Penilaian hendaknya digunakan untuk memeriksa sejauh mana perubahan tingkah laku siswa yang telah terjadi melalui proses belajarnya. Selain itu penilaian juga berperan memberikan umpan balik untuk memperbaiki proses pembelajaran yang telah digunakan. Disamping itu, penilaian bukan hanya tentang mengukur hasil belajar siswa di akhir program pembelajaran, tetapi juga memantau kemajuan siswa dan memberikan umpan balik sepanjang pembelajaran tersebut berlangsung.

Beberapa permasalahan dalam dunia pendidikan yang sering terjadi salah satunya adalah penilaian hasil belajar. Proses penilaian yang dilakukan selama ini masih bersifat konvensional atau tradisional. Di kutip dari Robles \& Braathen (2002) penilaian konvensional memposisikan peserta didik sebagai penerima pengetahuan dimana pembelajaran diukur dan didokumentasikan pada tingkat terendah dari taksonomi bloom's sebagai pengetahuan dan pemahaman. Pada proses pelaksanaannya, penilaian konvensional membutuhkan kertas dan alat tulis dalam menunjang proses penilaian. Cara ini dirasa kurang efisien karna membutuhkan biaya yang lebih banyak dalam menggandakan soal ujian dan menyiapkan lembar jawaban, serta kurang efektif dalam proses evaluasi, karena membutuhkan waktu yang lebih lama dalam 
proses penilaian, perekapan nilai sampai proses akhir hasil penilaian yang akan diberika kepada mahasiswa. Pada proses penilaian secara konvensional tidak dapat dilakukan secara real time, mahasiswa perlu menunggu untuk mengetahui hasil evaluasi pembelajaran meraka. Selain itu memiliki peluang subjektivitas yang cukup tinggi dalam pengolahan datanya.

Solusi mengenai permasalahan terhadap penilaian tersebut dapat diatasi dengan adanya teknologi informasi dan komputer dapat merubah sistem yang masih bersifat konvensional kedalam sistem yang berbantukan komputer atau terkomputerisasi berupa e-assessment. Guru sebagai salah satu komponen dalam proses pembelajaran harus terampil dalam menggunakan perangkat pembelajaran (model, media dan instrumen) yang tepat (Suranti, 2016).

Pada e-assessment, pelajar dapat berperan sebagai penulis dan evaluator umpan balik (Gogoulou et al, 2007). Santos et al (2015) mengungkapkan bahwa komputer menawarkan kemungkinan untuk menggunakan simulasi, mengelola sejumlah besar informasi yang diperbarui dan diperkaya, meningkatkan interaksi dengan informasi dan membuat peserta didik lebih partisipatif dalam proses penilaian. Selain itu, Sorensen (2013) mengungkapkan bahwa penilaian dengan sistem online menjadikan penilaian tersebut lebih efisien dalam hal waktu, pendanaan, dan pencapaian tujuan penilaian. Pada kondisi online, mampu membantu meminimalisir tingkat kecurangan mahasiswa setiap melaksanakan ujian dan mengurangi tingkat subjektivitas dalam pengolahan data.

\section{METODE PENELITIAN}

Metode yang digunakan dalam penelitian ini adalah penelitian dan pengembangan (Research and Development) atau yang biasa disebut dengan $\mathrm{RnD}$. Pemilihan metode $\mathrm{RnD}$ didasarkan atas jenis metode ini digunakan untuk menghasilkan dan menguji keefektifan produk tertentu (Sugiyono, 2013). Penelitian ini dilakukan 4 tahapan yaitu Decide (tahap memutuskan), Design (tahap mendesain), Develop (tahap pengembangan) dan Evaluate (tahap mengevaluasi) (Ivers \& Barron, 2002).

a. Tahap Decide, pada tahap ini dilakukan brainstorming, analisis konten, dan kajian literatur yang sesuai dalam mengembangakan e-assessmet. Banyak bagian yang diputuskan pada tahap ini seperti jumlah instrumen yang akan dikembangkan, jenis instrumen yang dipilih, materi fisika yang perlu dibuatkan instrumennya, perangkat pendukung apa saja yang dibutuhkan, serta siapa saja yang akan terlibat atau dilibatkan dalam penelitian ini.

b. Tahap Design, tahap ini dilakukan perancangan struktur pogram dan detail konten yang dipersiapkan untuk dikembangkan lebih lanjut. Pada bagian ini dihasilkan flowchart dan storyboard.

c. Tahap Development, pada tahap ini dilakukan pengembangan dan pembuatan media e-assessment berdasarkan flowcharat dan storyboard yang sudah didesain sebelumnya, melakukan review media dan merevisi kesalahan-kesalaan yang mungkin terjadi.

d. Evaluation, pada tahap ini dilakukan evaluasi secara menyeluruh. Setiap proses yang telah dilalui hingga menghasilkan produk e-assessment. Evaluasi dilakukan dengan serangkaian pengujian empiris yang melibatkan pengguna (mahasiswa dan dosen) dari model yang telah dikembangkan.

\section{HASIL DAN PEMBAHASAN}

Pengembangan penilaian online atau bisa disebut dengan e-assessment merupakan upaya untuk menggantikan penilain secara konvensional ke dalam penilaian berbasis komputer. Garrison \& Vaughan (2008) menyatakan bahwa dalam pembelajaran dan penilaian online terdapat beberapa keuntungan, 
diantaranya rekonseptualisasi dan redesain pembelajaran sehingga lebih menyegarkan (fresh), kemampuan mengatur konten lebih banyak, serta dapat menjadikannya sebagai komunitas inkuiri.

ICT (Information and Communication Technology) atau yang lebih dikenal sebagai teknologi informasi dan komunikasi dipandang sebagai sebuah alat untuk mendukung pembaruan kurikulum dan keyakinan pedagogik guru dari teacher-centered menuju ke student-centered (Nisrina, et al, 2016). Pemanfaatan ICT dalam pembelajaran dan penilaian dapat memberikan kemudahan bagi penggunanya (dosen dan mahasiswa), efektif dari berbagai situasi dan memiliki dampak positif dalam perkembangan keterampilan sikap dan pemahaman konsep siswa (Bhukuvhani et $a l, 2010)$.

Berdasarkan hasil observasi yang dilakukan beberapa masalah yang terjadi dalam penilaian antara lain: 1) tingginya biaya penggandaan perangkat dan instrumen, 2) analisis data dan umpan balik yang lebih lama, dan 3) peluang subjektivitas dalam pengolahan data yang cukup tinggi. Masalah tersebut dapat diatasi dengan pengembangan penialai secara online atau penilaian elektronik (e-assessment). Dalam pengembangan e-assessment dilakukan 4 tahapan yaitu Decide, Design, Develop dan Evaluate. Tahapan pada peneliitan ini fokus pada tahap decide dan design.

Tahapan pertama yaitu decide, dihasilkan analisis konten untuk menentukan kebutuhan yang akan digunakan dalam penelitian, menentukan kebutuhan software, hardware serta perangkat pendukungnya yang layak digunakan dalam proses pembuatan dan dalam menjalankan sistem e-assessment. Adapun spesifikasi minimum software yang digunakan adalah sistem operasi: windows XP Service pack , Windows Vista, Windows 7, untuk Moodle 3.3, PHP version 5.5, Database Mysql 5.5.31, Web Browser: Google Chrome 30.0, Mozilla Firefox 5.0 dan spesifkasi minmum hardware yang dapat digunakan adalah Processor : Intel Pentium 2.10 GHz, RAM 1 GB, Hard Drive 120 GB. Kebutuhan hardware disesuaikan dengan kebutuhan space yang lebih besar dengan bertambahnya materi pembelajaran dan banyaknya user aktif yang akan menggunakan moodle, selanjutnya memutuskan lokasi dan waktu penelitian, serta membuat instrumen materi fisika yang digunakan pada tahap uji coba awal, uji coba akhir hingga tahap evaluasi. Lokasi Penelitian akan dilaksanakan pada Pusat Teknologi Informasi dan Komunikasi (PUSTIK) UNRAM, Obyek Mahasiswa Semester VI Pendidikan Fisika, Materi kuliah pengembangan pembelajaran fisika, evaluasi pembelajaran fisika dan gelombang dan optik.

Tahapan kedua yaitu tahap design, mendesain flowchart dan storyboard $e$ assessment. Untuk rancangan flowchart terdiri dari flowchart proses log-in dan proses data pada e-assessment. Untuk rancangan storyboard terdiri dari storyboard rancangan tampilan awal sebelum log-in, rancangan tampilan proses log-in, rancangan tampilan memulai ujian, rancangan tampilan pertanyaan quiz ujian, rancangan tampilan penilain hasil ujian. Rancangan pada tahapan desain ini dipersiapkan untuk dikembangkan lebih lanjut.

Berikut rancangan flowchart dan storyboard yang telah didesain. 
Flowchart proses login e-assessment,

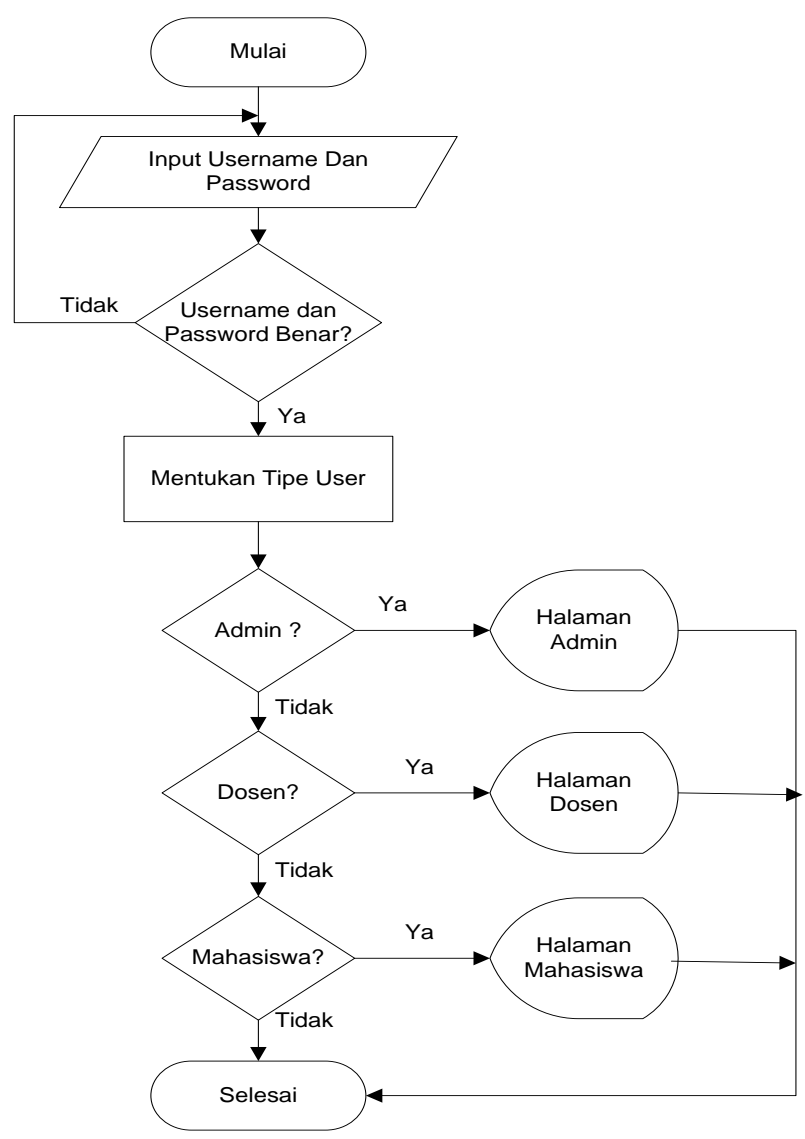

Gambar 1. Flowchart Proses Login

Flowchart proses login e-assessment,

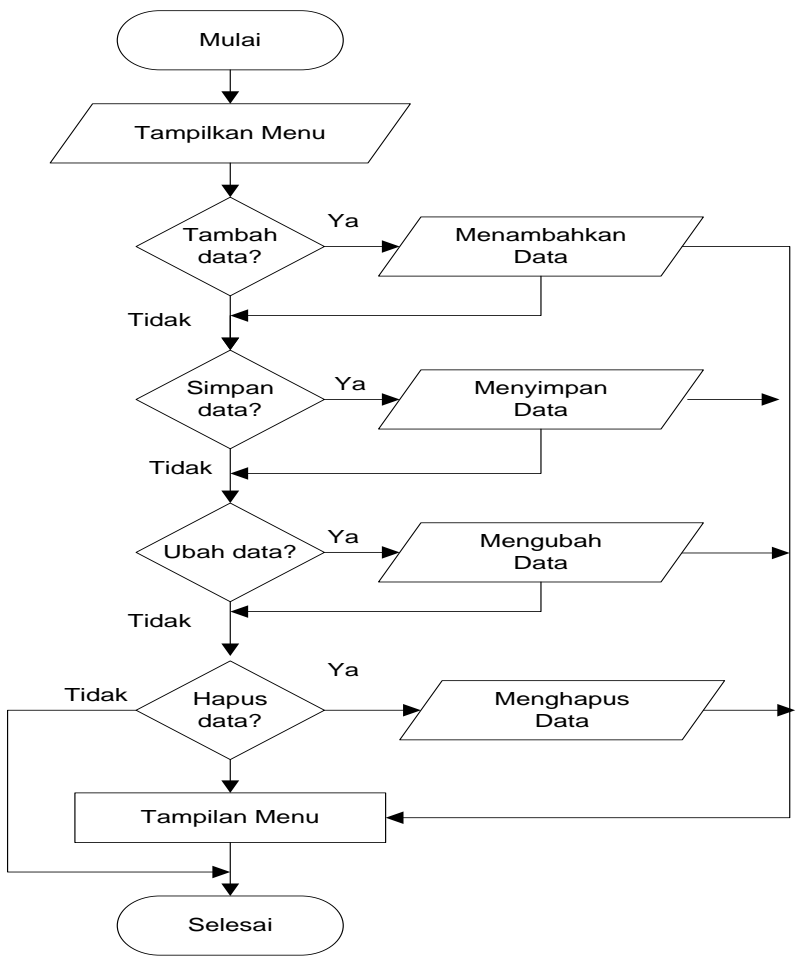

Gambar 2. Flowchart Proses Login e-Assessment,
Storyboard rancangan tampilan awal sebelum login

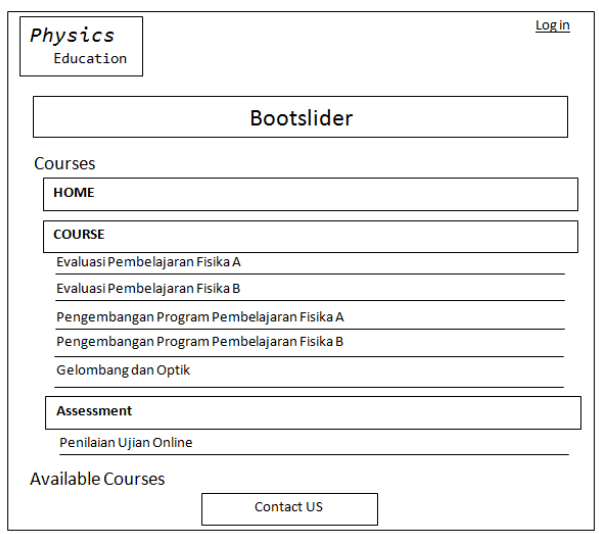

Gambar 3. Rancangan tampilan awal sebelum login

Storyboard Rancangan tampilan proses log-in,

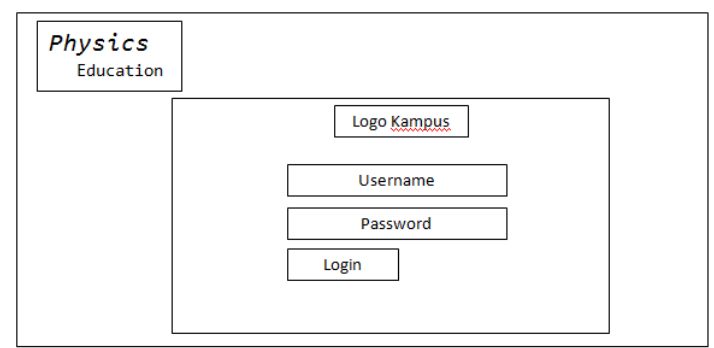

Gambar 4. Rancangan Tampilan Proses Log-In

Storyboard Rancangan tampilan memulai quiz

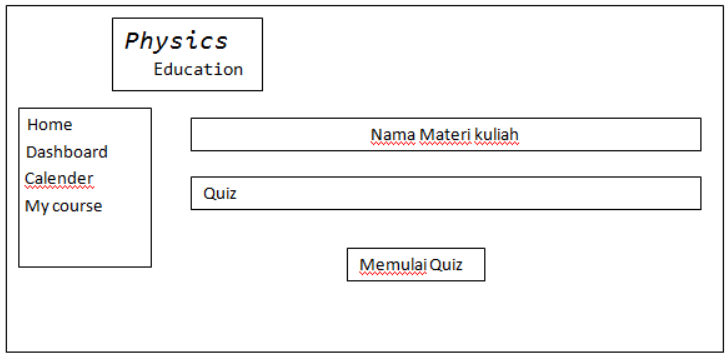

Gambar 5. Rancangan tampilan memulai quiz

Storyboard Rancangan tampilan halaman quiz

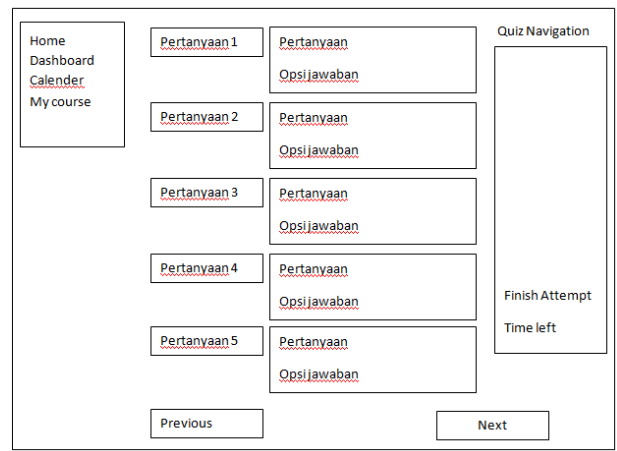

Gambar 6. Rancangan Tampilan Halaman Quiz 
Storyboard Rancangan Penilian Quiz

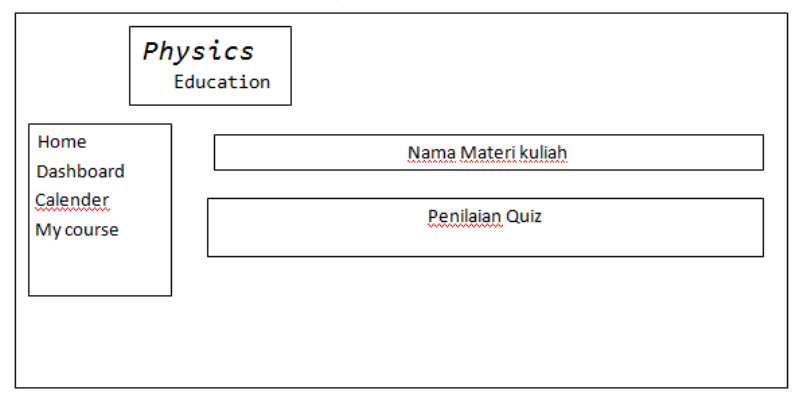

Gambar 7. Rancangan Penilian Quiz

\section{PENUTUP}

Berdasarkan hasil dan pembahasan diatas dapat disimpulkan bahwa pengembangan e-assessment merupakan upaya dalam menggantikan sistem ujian konvensional ke dalam sistem berbasis komputer. Dalam penelitian dan pengembangan ini dilakukan 4 tahapan, yaitu decide, design, develop dan evaluate. Hasil penelitian ini menujukkan desain sistem dari e-assessment yang terdiri dari 2 tahapan. Pertama tahap decide menentukan analisis konten, kebutuhan hardware dan software, lokasi penelitian, objek penelitian, materi fisika serta instrumen penelitian dan kedua tahap design menghasilkan flowchart dan storyboard.

Beberapa saran yang dapat diajukan oleh peneliti untuk mengoptimalkan pengembangan e-assessment meliputi meningkatkan fitur tampilan sistem agar lebih menarik dan pengembangan e-assessment dapat dimanfaatkan secara luas

\section{UCAPAN TERIMAKASIH}

Penulis menyampaikan ucapan terima kasih yang sebesar-besarnya kepada DP2M Dikti Kemendikbud yang telah memfasilitasi pembiayaan penelitian ini melalui Skim Penelitian Produk Terapan Tahun 2017.

\section{REFERENSI}

Bhukuvhani, C., Kusure, L., Munodawafa, V., Sana, A., \&Gwizangwe, I. 2010. Preservice Teachers' Use of Improvised and Virtual Laboratory Experimentation In
Science Teaching. International Journal of Education and Development using Information and Communication Technology, 6(4), 27

Finkelstein, N. D., Adams, W. K., Keller, C. J., Kohl, P. B., Perkins, K. K., Podolefsky, N. S., ... \& LeMaster, R. 2005. When Learning About The Real World is Better Done Virtually: A Study of Substituting Computer Simulations for Laboratory Equipment. Physical Review Special Topics-Physics Education Research, 1(1), 010103.

Gogoulou, A., Gouli, E., Grigoriadou, M., Samarakou, M., \& Chinou, D. 2007. A Web-Based Educational Setting Supporting Individualized Learning, Collaborative Learning and Assessment. Journal of Educational Technology \& Society, 10(4).

Gunawan, G., Harjono, A., \& Sutrio, S. 2015. Multimedia Interaktif dalam Pembelajaran Konsep Listrik bagi Calon Guru. Jurnal Pendidikan Fisika dan Teknologi, 1(1), 9-14.

Herga, N. R., \& Dinevski, D. 2012. Using A Virtual Laboratory to Better Understand Chemistry-An Experimental Study on Acquiring Knowledge. In Information Technology Interfaces (ITI), Proceedings of the ITI 2012 34th International Conference, 237-242.

Ivers, K. S., \& Barron, A. E. 2002. Multimedia Project in Education: Designing, Producing, and Assessing. USA: Libraries Unlimited

Nisrina, N., Gunawan, G., \& Harjono, A. 2016. Pembelajaran Kooperatif dengan Media Virtual untuk Peningkatan Penguasaan Konsep Fluida Statis Siswa. Jurnal Pendidikan Fisika dan Teknologi, 2(2), 66-72.

Robles, M., and Braathen, S. 2002. Online Assessment Techniques. Delta Pi Epsilon Journal, 44(1), 39-49.

Santos, P., Cook, J., \& Hernández-Leo, D. 2015. M-AssIST: Interaction and Scaffolding Matters in Authentic 
Assessment. Journal of Educational Technology \& Society, 18(2), 33.

Sorensen, E. 2013. Implementation and student perceptions of e-assessment in a Chemical Engineering Module. European Journal of Engineering Education, 38(2), 172-185.

Sugiyono. 2013.Metode Penelitian Kuantiatif Kualitatif dan R\&D. Bandung: Alfabeta

Suranti, N. M. Y., Gunawan, G., \& Sahidu, H. 2016. Pengaruh Model Project Based Learning Berbantuan Media Virtual Terhadap Penguasaan Konsep Peserta didik pada Materi Alat-alat Optik. Jurnal Pendidikan Fisika dan Teknologi, 2(2), 73-79. 